\title{
EVALUATION OF THE RESULTED ENERGY FROM EL HAMMAM SANITARY LANDFILL
}

\section{H. H. Mohamed*}

\section{ABSTRACT}

The study was conducted in El Hammam sanitary landfill at Alam Nayel to evaluate the resulted energy by measuring the emitted gas production, methane percent as one of the most important gas components, produced energy, energy consumption in landfill operation and finally leachat flow rate to optimize energy production from landfill. The landfill produces large amount of gas, which is burned without using it as a source of energy. The gas can be used to generate electricity or to be pumped in to pipeline gas to reduce energy costs and greenhouse gas emissions. The cumulative values of the produced gas, methane, thermal energy and electric energy were 1.93 million $\mathrm{m}^{3}, 768,226 \mathrm{~m}^{3}, 7665.2 \mathrm{M} . \mathrm{W} . \mathrm{h}$ and 2682.82 M.W.h respectively after 1860 day. The landfill electric consumption was about $43 \mathrm{M}$.W.h/year, which is generated by $11 \mathrm{~kW}$ diesel engine, consumes about 17,520 liter/year and produce $\mathrm{CO}_{2}$ emission of about 43,800 kg/year.

Key words: solid wastes, landfill gas, thermal energy, leachate.

\section{INTRODUCTION}

7 he management of solid wastes is considered one of the biggest problems in Egypt because it affects all aspects of citizen's life.

Zaki et al. (2013) reported that the amount of generated solid wastes in Egypt is from 0.3 to $0.8 \mathrm{~kg} /$ day/capita, with an annual growth of $3.4 \%$. The total annual generated solid wastes in Egypt have increased more than $36 \%$ since 2000 , to the current level of 20.5 million ton per year in 2013. In addition, there is 6.2 million ton/year industrial waste including 0.2 million ton of hazardous waste and 23 million ton/year of agricultural waste. El Beri, (2013) reported that the Egyptian municipal solid waste consists of $60 \%$ organic waste, $11 \%$ paper, $3 \%$ glass, $12 \%$ plastic, $2 \%$ textiles, $2 \%$ metal and $10 \%$ other.

*Lecturer, Soil \& Ag. Eng. Dept., Fac of Agric. Saba Basha, Alexandria University, Egypt. 
Al Seadi et al. (2008) reported that the increase in production of organic wastes is considered one of the main environmental problems, so that the sustainable waste management as well as waste prevention has become major political priorities, representing an important share of the common efforts to reduce pollution and greenhouse gas emissions and to mitigate global climate changes.

Egypt is the second largest dry natural gas producer in Africa. However, the production of the energy in Egypt has been steadily declining since 2009 and in 2012 reached 82,046 kilo tonne of oil equivalent. This is due to shortages in natural gas and oil production. The shortages have led to frequent electricity blackouts (Iea, 2016).

Ehrig et al. (2011) reported that landfill gas is a complex gas mixture created by the action of microorganisms in a landfill, which consists of methane $(\mathrm{CH} 4)$, carbon dioxide $\left(\mathrm{CO}_{2}\right)$ and trace gases such as hydrogen and sulphide.

The landfill gas is the result of three processes: 1- evaporation of volatile organic compounds, 2- chemical reactions between waste components, 3 -microbial action. The first and the second processes strongly depend on the nature of the waste. The main process in most landfills is the third process which the anaerobic bacteria decompose organic waste to produce biogas. Formation of methane and $\mathrm{CO}_{2}$ need about six months after depositing the landfill material. The production of gas reaches a maximum at about 20 years, then declines (UEIA, 2015).

Sullivan (2013) reported that landfills are the third largest source of human-made methane emissions in the United States. The gases produced within a landfill can be used in various ways. The landfill gas can be used directly on site by a boiler or any type of combustion system, providing heat. Electricity can also be generated on site by use of steam turbines, or fuel cells.

The landfill gas can be sold off site and sent into natural gas pipelines. This approach requires the gas to be processed into pipeline quality, e.g., by removing various contaminants and components (Sethi, 2013). The efficiency of gas collection at landfills directly can be affected the amount of energy that can be recovered in case of closed landfills (those no longer accepting waste), the collected gas produces more efficiently than open landfills (those that are still accepting waste) (EPA, 2013). 
The research was carried out:

1- To evaluate landfill gas quality and production.

2- To determine a blueprint for produce electric and thermal energy from gas.

3- To determine a blueprint for reduce greenhouse gas emissions from the landfill.

\section{MATERIALS AND METHODS}

The research was done at El Hammam sanitary landfill in Alam Nayel, Alexandria. The chemical analysis was conducted in the laboratory of Soil and Agricultural Engineering dept., Faculty of Agriculture Saba Basha, Alexandria University.

\section{1- Location and technical specification of landfill}

El Hammam landfill has been established for the disposal of waste collected from Alexandria, which is located $80 \mathrm{~km}$ in the south west of Alexandria city (30.754 N, $29.417 \mathrm{E})$ as shown in Fig. (1). The surface area of the landfill is 53.76 ha with cells height about $25-30 \mathrm{~m}$. The Landfill started in 2003 to receive about 510,000 ton of waste every 6 months (Onyx, 2006).

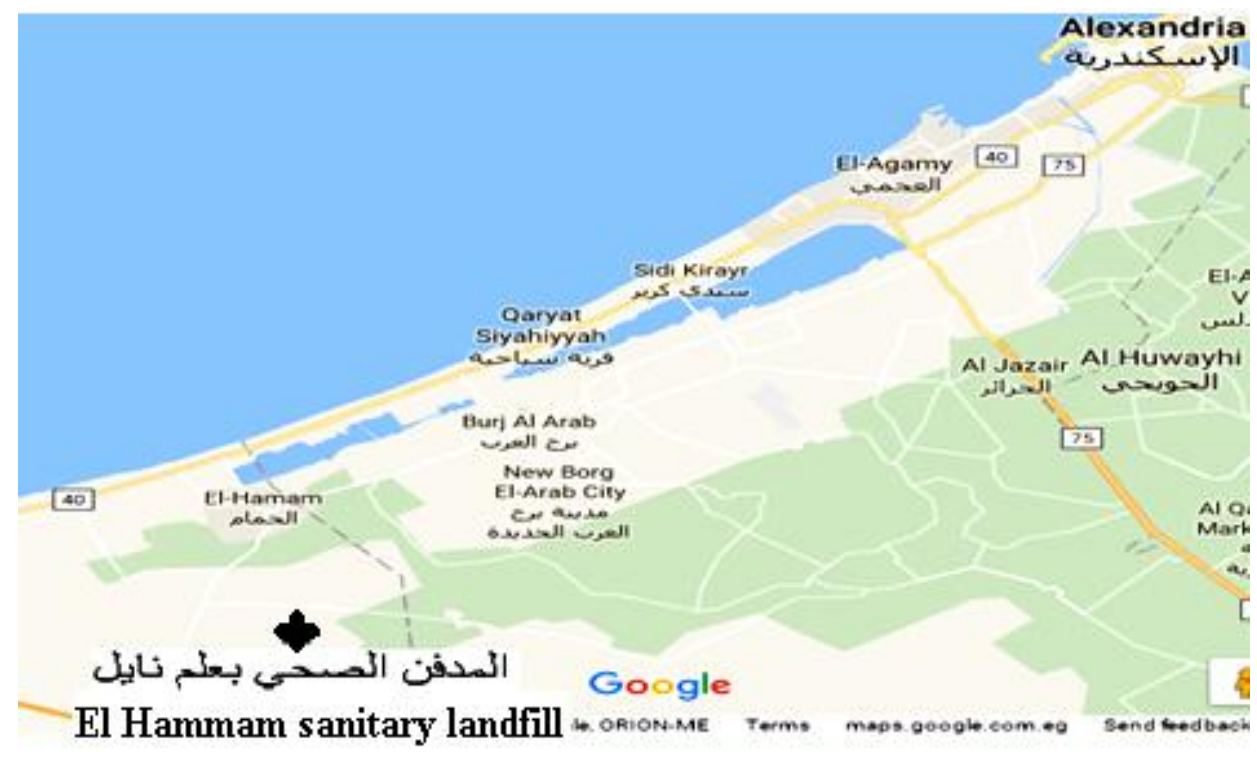

Fig. (1) : El Hammam landfill location.

The landfill consists of 11 cells, the cells from 1 to 7 equipped with biogas network, while the cells from 8 to 11 are not equipped with biogas network as shown in Fig. (2). 


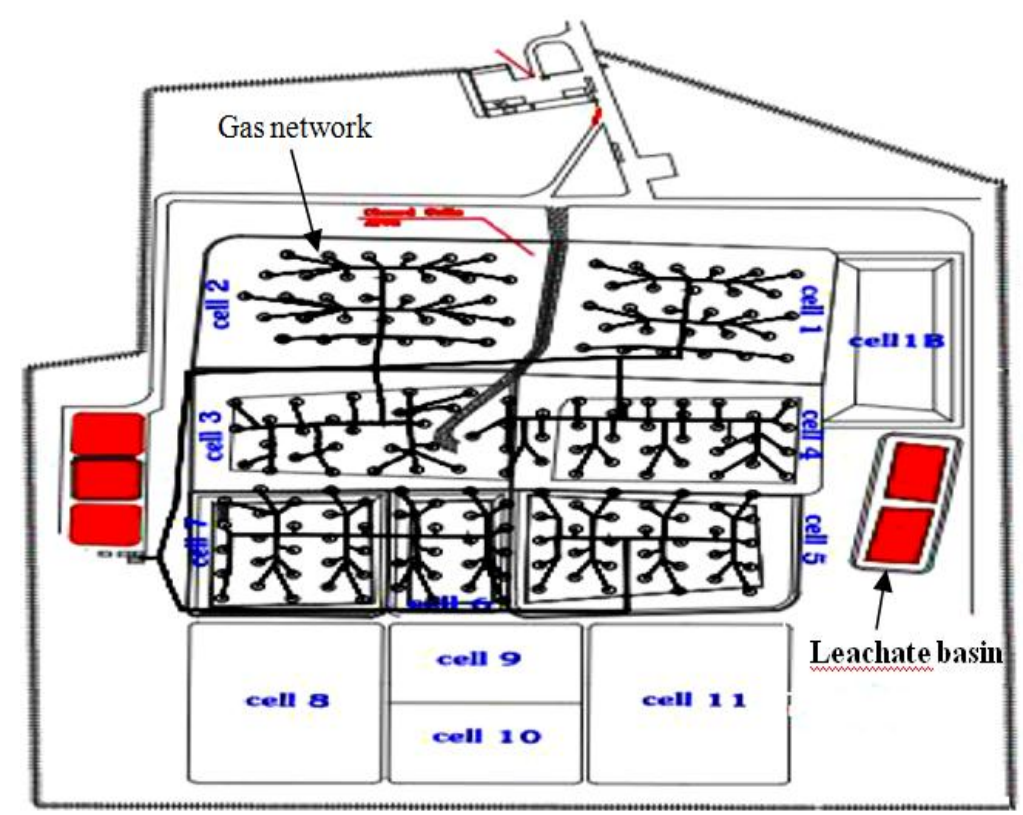

Fig.(2) : Diagram of landfill cells and gas network (1:20,000 scale).

The shape and the specification of each cell which include length, width, area and gas production are shown in Table (1) and Fig.(3). In order to increase methane percentage, a purification gas station was used to separate undesirable gases. The resulted liquid from waste decomposition in the cell is pumped towards leachate basins to vaporize the leachate by the sun. The leachate basins were isolated according to the environmental standards and technical specifications to protect the ground water.

Table (1). Cells dimensions and cumulative gas production (Onyx, 2006)

\begin{tabular}{ccccc}
\hline $\begin{array}{c}\text { No of } \\
\text { cell }\end{array}$ & $\begin{array}{c}\text { Length, } \\
\mathrm{m}\end{array}$ & Width, m & Area, $\mathrm{m}^{2}$ & $\begin{array}{c}\text { Cumulative gas } \\
\text { production, } \mathrm{m}^{3}\end{array}$ \\
\hline 1 & 204 & 190 & 38760 & $1,747,612$ \\
\hline 2 & 252 & 190 & 47880 & $2,158,815$ \\
\hline 3 & 233 & 100 & 23300 & $1,050,551$ \\
\hline 4 & 233 & 100 & 23300 & $1,050,551$ \\
\hline 5 & 166 & 156 & 25896 & $1,167,600$ \\
\hline 6 & 166 & 78 & 12948 & 583,800 \\
\hline 7 & 233 & 166 & 38678 & $1,743,915$ \\
\hline Total & & & 210762 & $9,502,845$ \\
\hline
\end{tabular}




\section{2- Sampling and analysis}

Six leachate samples were collected randomly from leachate basins in El Hammam sanitary landfills and analyzed to assess their physiochemical characteristics and heavy metals concentrations as presented in Tables ( 2 and 3 ).

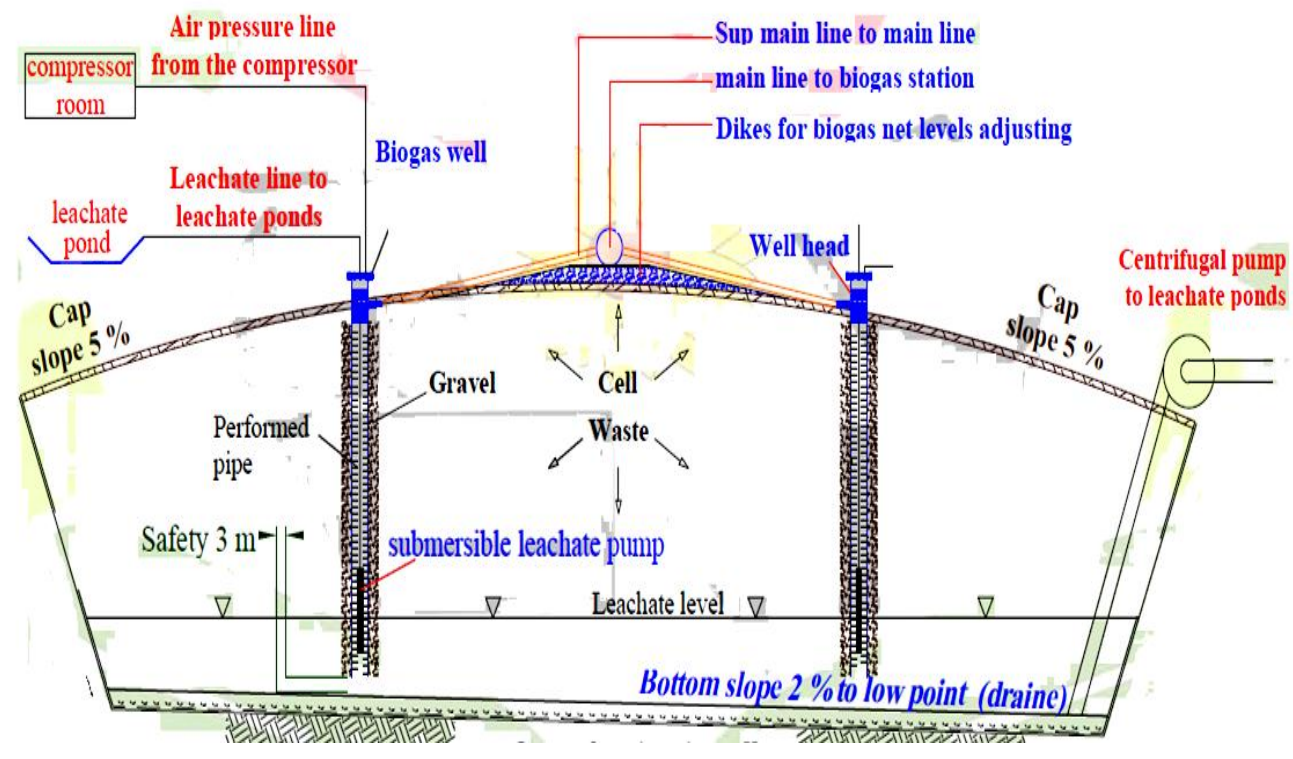

Fig.(3) : Diagram of cell cross section and gas network.

Table (2). Physical and chemical analyses of leachate samples.

\begin{tabular}{lccc}
\hline Parameters & Unit & Min value & Max value \\
\hline $\mathrm{PH}$ & - & 7.1 & 7.9 \\
\hline Conductivity & $\mu \mathrm{S} / \mathrm{cm}$ & 34,680 & 41,944 \\
\hline Total dissolved solids & $\mathrm{mg} / 1$ & 23,853 & 31,221 \\
\hline Chl orides & $\mathrm{mg} /$ & 9523 & 16,196 \\
\hline Total suspended solids & $\mathrm{mg} / 1$ & 3265 & 14,355 \\
\hline Chemical oxygen demand & $\mathrm{mg} / 1$ & 12,253 & 16,260 \\
\hline Biochemical oxygen demand & $\mathrm{mg} / 1$ & 9620 & 11,700 \\
\hline Total nitrogen & $\mathrm{mg} / 1$ & 386 & 956 \\
\hline Ammonia-N & $\mathrm{mg} / 1$ & 192 & 415 \\
\hline Nitrate-N & $\mathrm{mg} / 1$ & 0.35 & 2.92 \\
\hline Sulfates & $\mathrm{mg} / 1$ & 296 & 723 \\
\hline Phosphates & $\mathrm{mg} / 1$ & 0.28 & 0.51 \\
\hline
\end{tabular}


Table (3). Heavy metals concentrations at leachate samples.

\begin{tabular}{lccc}
\hline Heavy metals & Unit & Min value & Max value \\
\hline Nickel & $\mathrm{mg} / 1$ & 0.034 & 0.159 \\
\hline Lead & $\mathrm{mg} / 1$ & 0.009 & 0.023 \\
\hline Copper & $\mathrm{mg} / 1$ & 0.015 & 0.167 \\
\hline Manganese & $\mathrm{mg} / 1$ & 0.258 & 1.400 \\
\hline Chromium & $\mathrm{mg} / 1$ & 0.027 & 0.092 \\
\hline Cadmium & $\mathrm{mg} / 1$ & 0.002 & 0.261 \\
\hline Zinc & $\mathrm{mg} / 1$ & 0.339 & 0.969 \\
\hline Iron & $\mathrm{mg} / 1$ & 0.423 & 11.500 \\
\hline
\end{tabular}

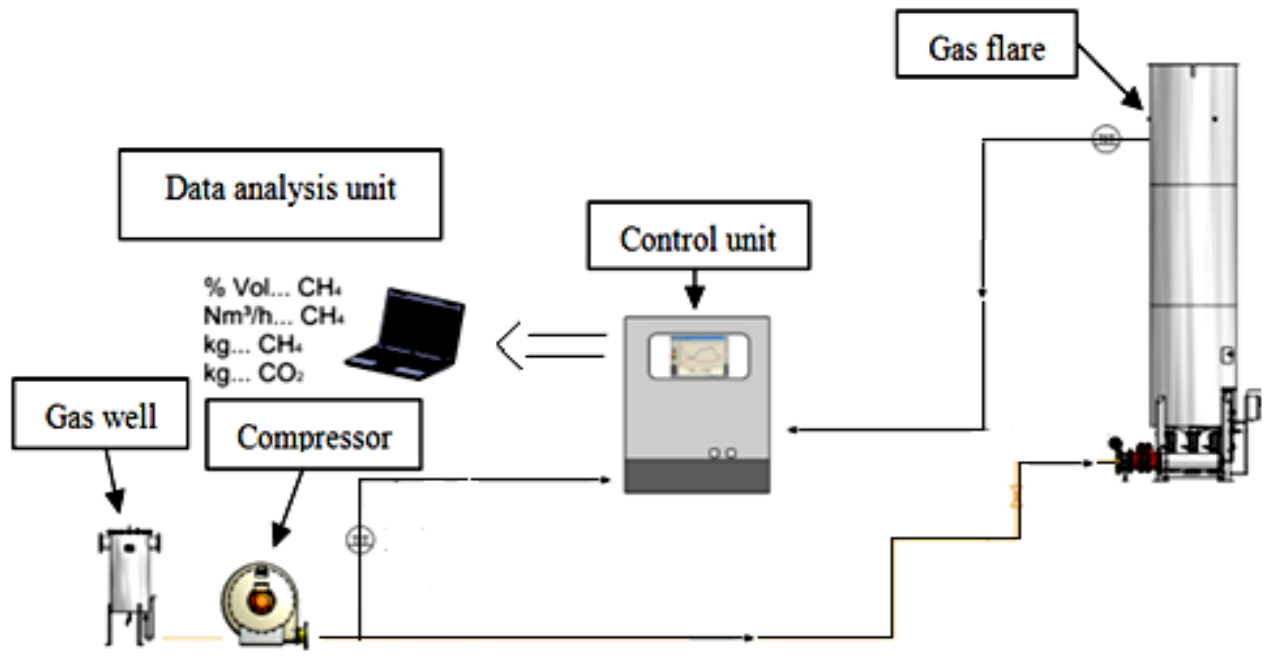

Fig. (4): CDM gas flare system.

\section{3 - Instrumentation}

\section{3-1 (CDM) gas flaring system}

The Clean Development Mechanism (CDM) system is a continuous monitoring with verifiable records that demonstrate methane destruction, which consists of:

A- Compressor for gas pumping from the well to the flare systems as shown in Fig. (4).

B- Control unit to measure biogas constituents, temperature, flow rate and automatic monitor gas flare.

C - Gas flare to burn gas and forwarding of gas quantity and combustion data. 
3-2 A portable biogas analyzer (Landtec GEM 2000) was used to monitor landfill gas (LFG) extraction systems, flares, migration control systems and to measure the percentage of $\mathrm{CH}_{4}(0-100 \%), \mathrm{CO}_{2}(0-$ $100 \%), \mathrm{O}_{2}(0-25 \%), \mathrm{H}_{2}$ (0-1000ppm), $\mathrm{NH}_{3}$ (0-1000ppm) and $\mathrm{H}_{2} \mathrm{~S}(0-$ 10,000ppm) in the biogas as shown in Fig (5).

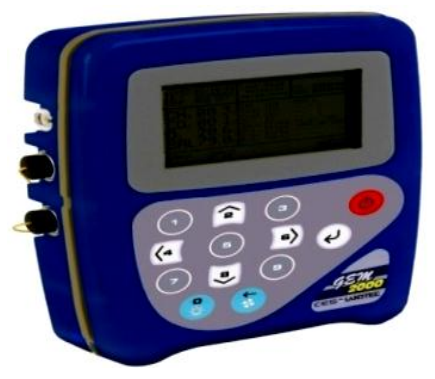

Fig. (5): Portable gas analyzer ( Landtec GEM 2000 ).

3-3 The ENDRESS HAUSER volumetric flow meter as shown in Fig.(6) was used to measure the volumetric flow rate of a landfill gas, $\left(\mathrm{m}^{3} / \mathrm{h}\right)$ with an accuracy of $+/-0.01$ at ambient temperature: from $-20^{\circ} \mathrm{C}$ to $+60^{\circ} \mathrm{C}$ and maximum pressure of $100 \mathrm{bar}$.

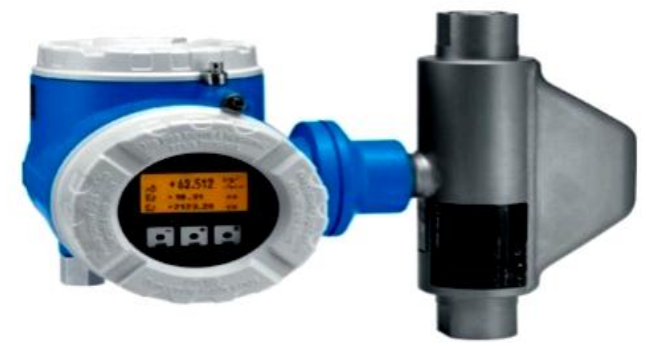

Fig. (6): ENDRESS HAUSER flow meter.

\section{4- Anaerobic biodegradation of municipal solid waste (MSW)}

The organic wastes start to undergo biochemical reactions, after MSW is landfilled. The natural organic compounds are oxidized aerobically in the presence of air near the surface of the landfill. The reaction is similar to combustion because the products are carbon dioxide and water vapor. However, the anaerobic digestion is the principal process in landfills, which takes place in three stages. In the first stage, the fermentative bacteria hydrolyze the complex organic matter into soluble molecules. In the second stage the molecules are converted by acid forming bacteria to 
simple organic acids, carbon dioxide and hydrogen; the principal acids produced are acetic acid, propionic acid, butyric acid and ethanol. Finally, in the third stage, methane is formed by methanogenic bacteria, either by breaking down the acids to methane and carbon dioxide as shown in the chemical reaction below (Themelis et al. 2006).

$$
\mathrm{C}_{6} \mathrm{H}_{12} \mathrm{O}_{6} \rightarrow 2 \mathrm{C}_{2} \mathrm{H}_{5} \mathrm{OH}+2 \mathrm{CO}_{2} \text {. }
$$

$$
\begin{aligned}
& \text { Methanogenesis } \\
& \qquad \mathrm{CH}_{3} \mathrm{COOH} \rightarrow \mathrm{CH}_{4}+\mathrm{CO} \\
& \mathrm{CO}_{2}+4 \mathrm{H}_{2} \rightarrow \mathrm{CH}_{4}+2 \mathrm{H}_{2} \mathrm{O} .
\end{aligned}
$$

\section{5- Methane production}

The amount of methane production from the landfill can be calculated using the following equation.

Methane production, $\mathrm{m}^{3} / \mathrm{h}=$

Landfill gas production $\mathrm{m}^{3} / \mathrm{h} \times$ Methane percent in landfill gas

\section{6- Energy production}

The amount of thermal energy generated from the landfill gas can calculated using the following equation according to Surroop et al. (2011).

$$
\text { Eth }=\frac{\text { FCH4 } \times \text { LHVCH4 }}{3600}
$$

The amount of electrical energy could be computed using the following equation according to Surroop et al. (2011).

$$
\text { Eel }=\frac{\text { FCH4 } \times \text { LHVCH4 } \times \eta \text { ef }}{3600}
$$

Where:

Eth - The thermal energy, kW.h.

FCH4 - Flow rate of $\mathrm{CH} 4, \mathrm{~m}^{3} / \mathrm{h}$.

LHVCH4 - Methane lower heating value of $36000 \mathrm{~kJ} / \mathrm{m}^{3}$

Eel- Electrical energy, kW.h

$\eta$ ef - Electrical efficiency of 35\%

\section{RESULTS AND DISCUSSION}

\section{1- Landfill gas production}

The relationships between daily and cumulative landfill gas production per $\mathrm{m}^{3}$ and the time per day are shown in Fig.(7). In general the graph showed that the landfill gas production increases by increasing the time 
until reach the maximum value and then the production starts to decrease. The cumulative landfill gas production increases by increasing the time until reach the maximum value of 1.93 million $\mathrm{m}^{3}$ after 1860 day for the total cells area and volume of $210,762 \mathrm{~m}^{2}$ and of 5.26 million $\mathrm{m}^{3}$ respectively. It was observed that the highest biogas production was 2598 $\mathrm{m}^{3} /$ day after 1296 day, while the lowest gas production was $198 \mathrm{~m}^{3} /$ day in the beginning of production. There are five stages of gas productions. The averages daily gas production were 429, 907, 1366, 2389 and $1632 \mathrm{~m}^{3}$ at 680 day for the first stage, 324 day for the second stage, 197 day for the third stage, 97 day for the fourth stage and 563 day for the fifth stage respectively as presented in Tables(4).

It was observed that the first stage is the lowest gas production because it is aerobic fermentation stage, which the aerobic microorganisms deplete oxygen and produces nitrate in leachate. Whereas the fourth stage is the highest gas production because solid waste was at full degradation and oxygen is no longer present in the landfill.

The gas will continue to be emitted for 20 or more years if a landfill receiving higher than average amounts of domestic animal waste.

(Crawford and Smith 1985).

A polynomial equation was determined to calculate cumulative gas production, $\mathrm{m}^{3} /$ day after any period of time, day as shown in Fig.(7).

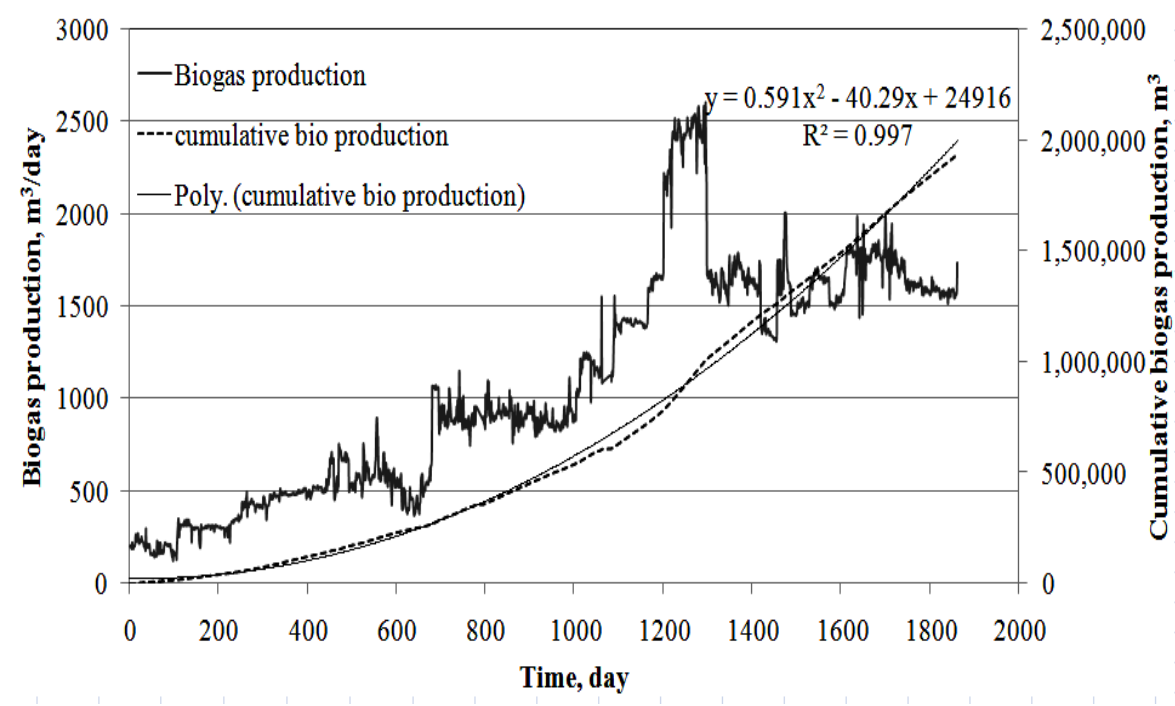

Fig. (7): Daily and cumulative landfill gas production. 


\section{1-1 Factors Affecting landfill gas production \\ 1-1-1Waste Composition}

There is no classifying unit at El Hammam sanitary landfill to classify the municipal solid waste into organic and inorganic wastes which lead to decrease gas production. Some types of organic waste contain nutrients, such as sodium, potassium, calcium, and magnesium, which activate bacteria, while some wastes contain salt concentrations that harm bacteria and decrease gas production (Crawford and Smith 1985). The more organic waste present in a landfill, the more methane is produced by bacterial decomposition, so to increase gas production at El Hammam sanitary landfill a classifying unit should be used to separate inorganic wastes from solid wastes.

\section{1-1-2 The content of oxygen}

The oxygen is available inside loosely buried waste, so that aerobic bacteria consume oxygen and produce carbon dioxide and water, while if the waste is highly compacted. methane production will begin earlier as the aerobic bacteria are replaced by anaerobic bacteria (Tecle et al. 2008), so the organic wastes at El Hammam sanitary landfill should be highly compacted to start the methane production early.

\section{1-1-3 Moisture Content}

The moisture content of organic wastes is important factor affecting on gas production. The moisture content of $40 \%$ or higher increases gas production because moisture encourages bacterial growth and transports nutrients and bacteria (Tecle et al. 2008).

The leachate can be used to increase wastes moister content by pumping it inside the landfill.

\section{1-1-4 Temperature}

The landfill temperature is controlling bacterial activity and gas production. The best temperature range for landfill is between 25 and $45^{\circ} \mathrm{C}$ to increase bacterial activity, while temperature below $10^{\circ} \mathrm{C}$ decreases bacterial activity dramatically (Tecle et al. 2008). Weather changes have a far greater effect on gas production in shallow landfills. A capped landfill usually maintains a stable temperature, maximizing gas production. An automatic control unit with solar heating system can be 
used to control the temperature of El Hammam sanitary landfill without using extra electric energy.

\section{1-1-5 Age of Refuse}

Landfills usually produce appreciable amounts of gas within 1 to 3 years. Peak gas production usually occurs 5 to 7 years after wastes are dumped. Almost all gas is produced within 20 years after waste is dumped; however, small quantities of gas may continue to be emitted from a landfill for 20 or more years (Tecle et al. 2008).

\section{2- Methane production}

The landfill gas consists of many types of gases, the methane is considers the most valuable gas because it can be use as a source of energy. So the highest methane percent of the landfill gas the highest price reach. The relationships between daily and cumulative methane production per $\mathrm{m}^{3}$ and the time per day are shown in Fig.(8). In general the methane production graph takes the same trend of landfill gas production because the amount of produced methane, $\mathrm{m}^{3}$ depends on biogas production, $\mathrm{m}^{3}$ and the percent of methane in biogas.

The cumulative methane production increases by increasing the time until reach the maximum value of $768,226 \mathrm{~m}^{3}$ after 1860 day for the total area.

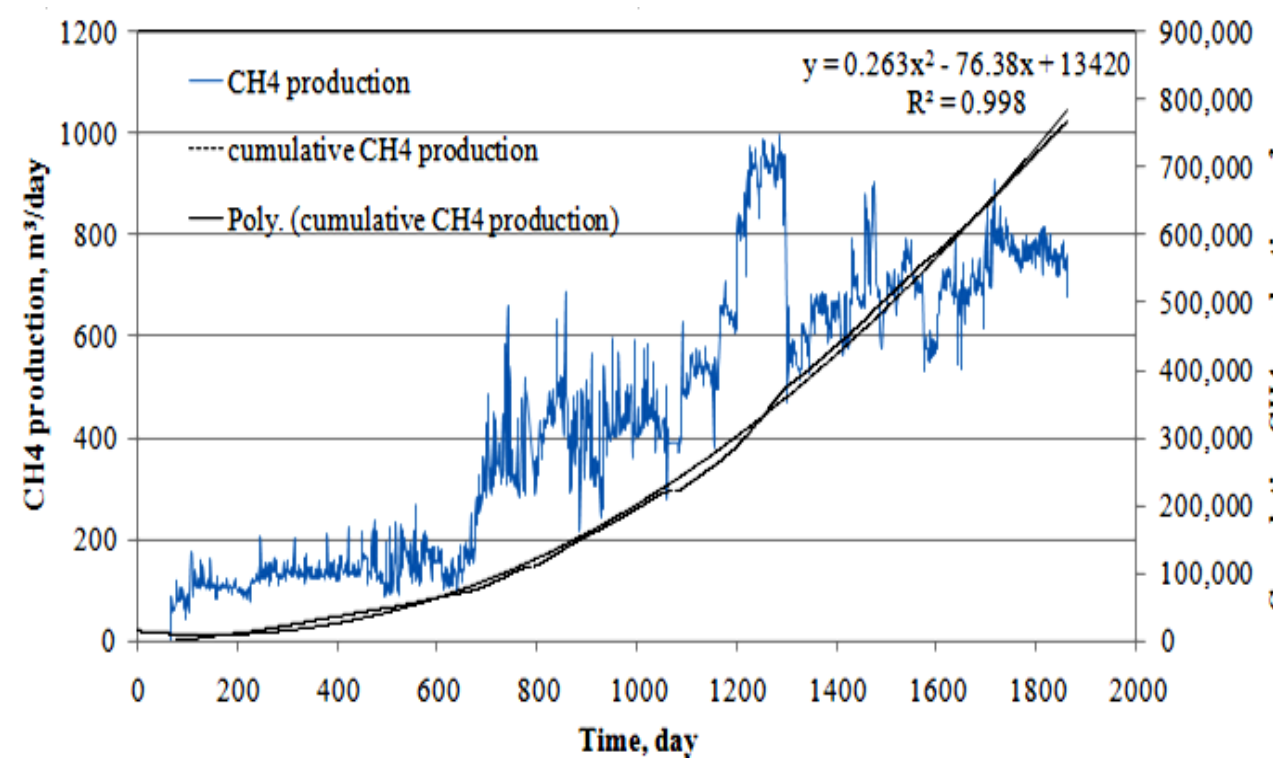

Fig. (8) : Daily and cumulative methane production. 
It was observed that the highest methane production was $995.11 \mathrm{~m}^{3} /$ day after 1286 day, while the lowest methane production was $42 \mathrm{~m}^{3} /$ day in the beginning of landfill production. There are five stages of methane productions. The average daily methane productions were $121.45,400.63$, $515.92,905.09$ and $697.18 \mathrm{~m}^{3}$ at the first, the second, the third, the fourth and the fifth stage respectively.

It was observed that the first stage is the lowest methane production because the aerobic bacteria consume oxygen and produce each of carbon dioxide and water. If the waste is highly compacted, however, methane production will begin earlier as the aerobic bacteria are replaced by methane-producing anaerobic bacteria. The fourth stage is the highest methane production because it is the highest gas production and methane percent.

A polynomial equation was determined to calculate cumulative methane production, $\mathrm{m}^{3} /$ day after any period of time, day as shown in Fig.(8).

\section{3- Thermal energy production}

The landfill produces large amount of gas, which is disposed by flaring system to destroy methane, compounds in the LFG such as volatile organic compounds and ammonia. This large amount of landfill gas isn't used in energy production, while gas can be used to generate electricity or to pump in to pipeline gas, which can solve many problems like controlling energy costs and reducing greenhouse gas emissions.

The relationship between daily and cumulative thermal energy production per kW.h and the time per day are shown in Fig.(9). In general the energy production graph takes the same trend of landfill gas production because the energy production depends on biogas production, $\mathrm{m}^{3}$ and the percent of methane in biogas. It was observed that the highest daily energy production was $9951 \mathrm{~kW} . \mathrm{h}$ after 1286 day, while the lowest daily energy production was $421 \mathrm{~kW} . \mathrm{h}$ in the beginning of the production. There are five stages of energy productions. The average daily energy productions were $1214.59,4006.35,5159.19,9050.9$ and $6987.8 \mathrm{~kW}$.h at the first, the second, the third, the fourth and the fifth stage respectively.

It was observed that the first stage is the lowest energy production because it is the lowest gas production, while the fourth stage is the highest energy production because it is the highest gas production stage. 


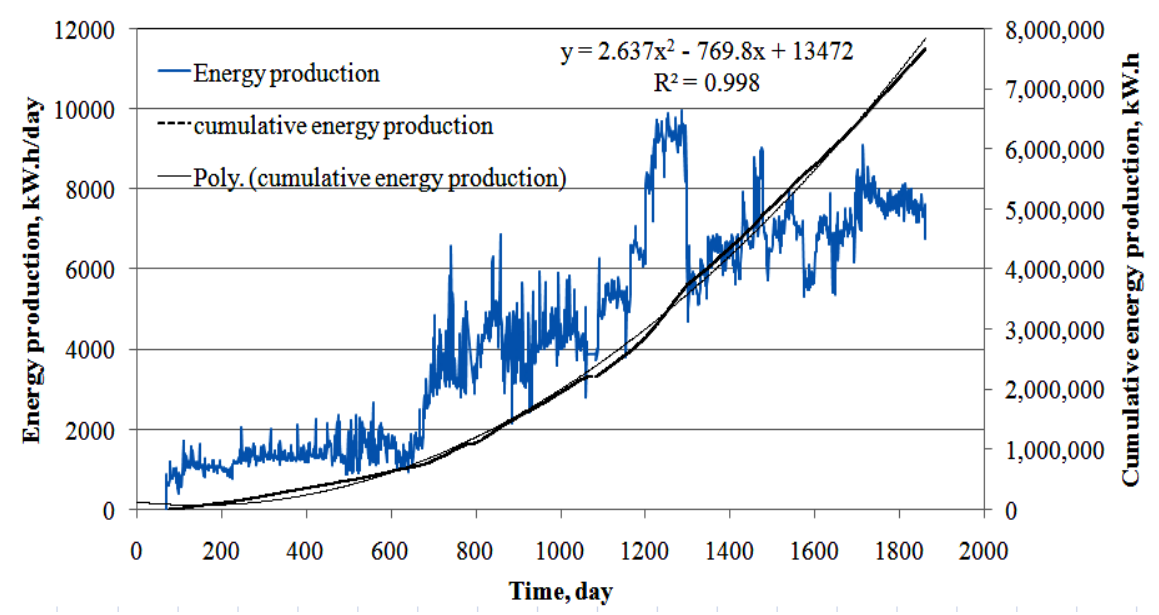

Fig. (9) : Daily and cumulative thermal energy production.

Table (4). Landfill gas production stages

\begin{tabular}{|c|c|c|c|c|c|c|}
\hline $\begin{array}{c}\text { Stage } \\
\text { No }\end{array}$ & $\begin{array}{c}\text { Time period, } \\
\text { day }\end{array}$ & \multicolumn{5}{|c|}{ Average production } \\
\cline { 3 - 7 } & & $\begin{array}{c}\text { Biogas, } \\
\mathrm{m}^{3}\end{array}$ & $\mathrm{CH} 4, \%$ & $\begin{array}{c}\mathrm{CH}^{3}, \\
\mathrm{~m}^{3}\end{array}$ & $\begin{array}{c}\text { O2, } \\
\%\end{array}$ & $\begin{array}{c}\text { Energy, } \\
\text { kW.h }\end{array}$ \\
\hline 1 & 680 & 429 & 30.5 & 121.45 & 9.5 & 1214.59 \\
\hline 2 & 324 & 907 & 44.23 & 400.63 & 7.4 & 4006.35 \\
\hline 3 & 197 & 1366 & 37.74 & 515.92 & 9.2 & 5159.19 \\
\hline 4 & 97 & 2389 & 37.87 & 905.09 & 9.87 & 9050.9 \\
\hline 5 & 563 & 1632 & 42.93 & 697.18 & 6.1 & 6987.8 \\
\hline
\end{tabular}

An electrical efficiency of $35 \%$ can be used to calculate the amount of generated electricity from thermal energy according to (Surroop et al. 2011). The cumulative thermal energy production increases by increasing the time until reach the maximum value of 7665.2 M.W.h after 1860 day, which can transfer to 2682.82 M.W.h of electric energy.

Operating landfill consume about 219 M.W.h of electric energy through 1860 day in management and operating lighting system, computer, blower, pumps and flare system. This energy is generated by $11 \mathrm{~kW}$ diesel engine which consumes about 17,520 liter/year. The CO2 emission from diesel fuel is about $43800 \mathrm{~kg} / \mathrm{year}$, so it is better to obtain the required electric energy in landfill operation from landfill gas instead of the diesel engine; this will also reduce greenhouse gas emissions and decrease fuel costs.

\section{3-1 Landfill gas utilization systems}

Biogas can be used in the production of heat and power, injection into the gas grid and as a transport fuel. The biogas must be treated before use to achieve the gas standards of each application. 
The most common biogas conversion technologies are outlined below.

\section{3-1-1 Combustion of biogas to generate heat}

Biogas has a calorific value between 21-23 $\mathrm{MJ} / \mathrm{m}^{3}$ and can be burned directly in a boiler to generate hot water or steam. This is a simple system, and reason for this solution not being the most used must be the fact that the price per $\mathrm{kW}$ power produced is almost higher than the price per $\mathrm{kW}$ heat. The heat can be exported but the cost of the infrastructure to transport the heat may be many times that of the boiler itself.

The heat from some boiler systems is used in greenhouses, either by normal circulation of hot water, or by heating of air that is blown into the greenhouses. This is also a relatively simple and efficient way to use the gas (Willumsen, 2001).

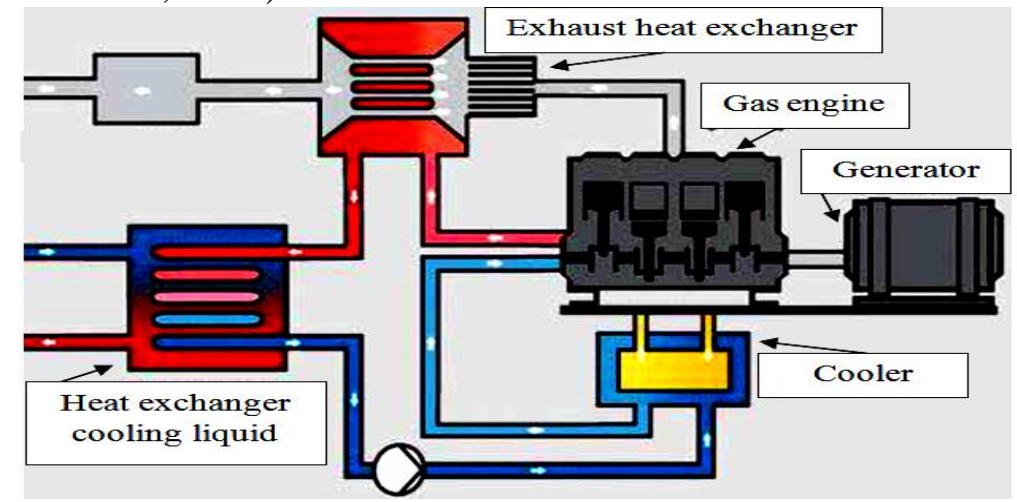

Fig. (10) : components of combined heat and power system.

\section{3-1-2 Combined heat and power system (CHP).}

Combined heat and power (CHP) is the conversion of the biogas fuel into heat and electricity. CHP plants are the most efficient system for utilizing the energy from landfills. The overall efficiency of CHP is around $85 \%$, which is divided in to $35 \%$ electric energy and 50\% heat energy (Willumsen, 2001). The CHP unit in a landfill gas plant usually consists of a reciprocating gas engine powers a generator that produces electricity. During operation, the reciprocating engine warms up, producing heat which is recovered by the oil cooling system, and emits large amounts of heat to the atmosphere in the form of exhaust gases. In CHP system, both types of heat are recovered by a heat exchanger system as shown in Fig.(10). The heat energy from the generator is available in engine jacket cooling water, engine lubrication oil cooling, First stage air intake intercooler, engine exhaust gases and engine generator radiated heat. The 
first three heat sources are recoverable in the form of hot water at temperature of $70-90^{\circ} \mathrm{C}$, while the engine exhaust gases typically leave the engine temperature between 400 and $500^{\circ} \mathrm{C}$, which can be used directly for drying leachate in a heat boiler to generate steam or via an exhaust gas heat exchanger combining with the heat from the cooling circuits (Sarah, 2007). The heat from the second stage intercooler is also available for recovery as a lower grade heat. Alternatively new technologies are available for the conversion of heat to further electricity, such as the Organic Rankine Cycle Engine.

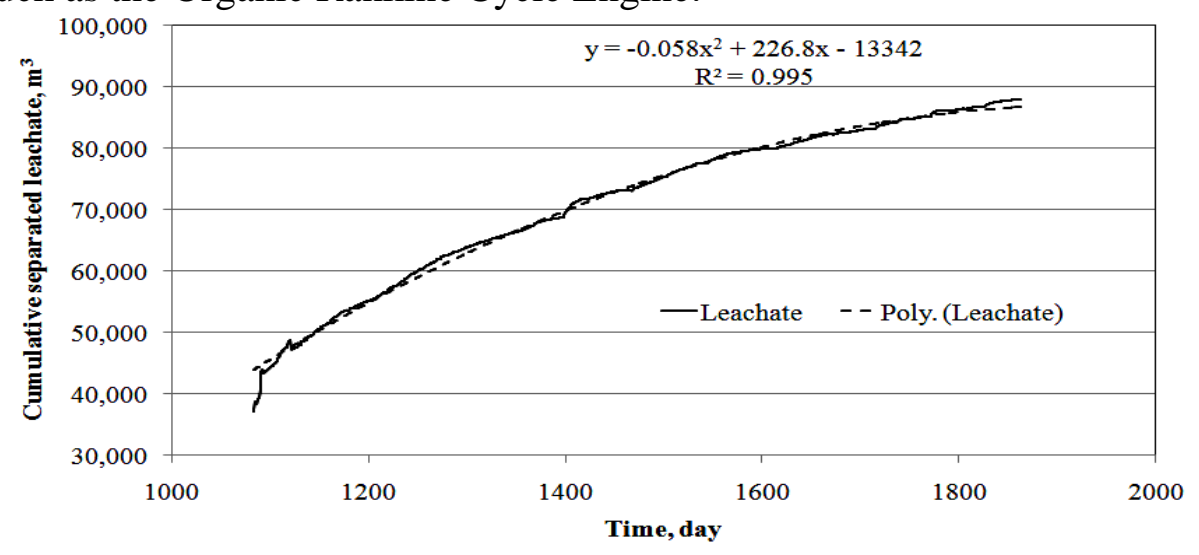

Fig. (11) : Cumulative landfill gas production.

\section{4- Landfill leachate}

The extracted leachate from the landfill was analyzed to evaluate the environmental impacts associated with solid waste landfilling. The results of physico-chemical analyses confirmed that the leachate characteristics were highly variable with sever contamination of organics, salts and heavy metals as presented in Tables ( 3 and 4 ). The leachate cannot be use in irrigation or in industry but it should be disposed by safe way to protect underground water and environment.

The presence of moisture (unsaturated conditions) in a landfill increases gas production because it encourages bacterial decomposition.

Moisture may also promote chemical reactions that produce gases at saturated conditions of the wastes so it is very important to extract leachate from the cells.

The relationship between the cumulative extracted leachate, $\mathrm{m}^{3}$ and the time, day are shown in Fig.(10). In general the cumulative extracted leachate increases by increasing the time until reach the maximum value of $87,917.2 \mathrm{~m}^{3}$ after 1860 day. 
The extracted leachate from the landfilled waste is transported off site to the nearest wastewater treatment facility but this method cost a lot of money and need more efforts. So we can burn landfill gas in a boiler to evaporate leachate and generate hot water or steam. The evaporated steam was directed to a steam turbine to generate electricity. A polynomial equation was determined to calculate cumulative extracted leachate, $\mathrm{m}^{3}$ after any period of time, day as shown in Fig.(10).

\section{CONCLUSIONS}

The cumulative values of gas production, methane production and energy production were increased by increasing the time until reach the maximum value of 1.93 million $\mathrm{m}^{3}, 768,226 \mathrm{~m}^{3}$ and 7665.2 M.W.h respectively after 1860 day for the total cells area of $210,762 \mathrm{~m}^{2}$ and volume of 5.26 million $\mathrm{m}^{3}$ respectively. The highest values of biogas production, methane production and energy production were 2598 $\mathrm{m}^{3} /$ day, $995.11 \mathrm{~m}^{3} /$ day and $9951 \mathrm{~kW} . \mathrm{h}$ respectively after 1296 day, while the lowest values were $198 \mathrm{~m}^{3} /$ day, $42 \mathrm{~m}^{3} /$ day and $421 \mathrm{~kW} . \mathrm{h}$ respectively in the beginning of landfill production.

The cumulative electric energy production was 2682.82 M.W.h after 1860 day. The landfill consumes about 219 M.W.h of electric energy through 1860 day in management and operating landfill. The electric energy is generated by $11 \mathrm{~kW}$ diesel engine which consumes about 17,520 liter/year. The $\mathrm{CO} 2$ emission from diesel fuel was about $43800 \mathrm{~kg} / \mathrm{year}$. A Combined heat and power system (CHP) is the most efficient system for converting produced landfill gas into 50\% heat energy and 35\% electric energy to reduce greenhouse gas emissions and decrease fuel costs.

\section{REFERENCES}

Al Seadi, T., Rutz, D., Prassl and R. Janssen, 2008. Biogas Handbook. Published by University of Southern Denmark Esbjerg, Niels Bohrs Vej, DK-6700 Esbjerg, Denmark, pp. 9-10.

Crawford, J. and Smith, P. 1985. Landfill technology. London: Butterworths.

El Beri, A. 2013. Egyptian Environmental Affairs Agency, Annual Report, EEAA. http://www.eeaa.gov.eg.

EPA 2013. Landfill Methane Outreach program". EPA.

Ehrig, H. J.; H. J. Schneider, and V. Gossow, 2011. Encyclopedia of Industrial Chemistry. Wiley-VCH, Weinheim.doi:10.1002 /1435. 
Iea, 2016. World Energy Outlook. International Energy Agency, ISBN Print: 978-92-64-26494-6 / PDF: 978-92-64-26495-3.

Onyx, 2006. Landfill Gas Capture and Flaring Project. El Hammam Landfills Alexandria, Egypt Version 4-April 2006

Powell, Jon T.; Townsend, Timothy G.; Zimmerman, Julie B. (2015). Estimates of solid waste disposal rates and reduction targets for landfill gas emissions". Nature Climate Change. online publication.doi:10.1038. ISSN 1758-6798.

Sarah, J. and P.E. Simon, 2007. Landfill Gas as Fuel for Combined Heat and Power. Cogeneration and Distributed Generation Journal. Vol. 22, No. 4.

Sethi, P. 2013. Landfill Gas Power Plants. California Energy Commission. Retrieved 27 September 2013.

Sullivan, P. 2013. The importance of landfill gas capture and utilization in the U.S. Council for Sustainable Use of Resources, Earth Engineering Center, Columbia University.

Surroop, D. and R. Mohee, 2011. Power Generation from Landfill Gas. 2nd International Conference on Environmental Engineering and Applications IPCBEE vol.17. IACSIT Press, Singapore.

Tecle, D.; J. Lee, and S. Hasan, 2009. Quantitative analysis of physical and geotechnical factors affecting methane emission in municipal solid waste landfill. Environ Geol 56:1135-1143.

Themelis, N. J; P. A. Ulloa, 2006. Methane generation in landfills. Earth Engineering Center and Department of Earth and Environmental Engineering, Columbia University,New York, NY 10027, USA.

UEIA, 2015. Landfill Gas and Biogas. U.S. Energy Information Administration. U.S. department of energy, sw. Washington, DC 20585.

Willumsen, H. 1997. Production and use of landfill gas. Energy Recovery, paper for Inte. Confer. on Solid Waste Management and Technology, 1997, LFG Consult, DK-8800 Viborg, Denmark.

Willumsen, H. 2001.Energy Recovery from Landfill Gas in Denmark and Worldwide, LFG Consult, DK-8800 Viborg, Denmark.

Zaki, T.; A. G. Kafafi,; M. B. Mina, and A. E. Mohamed, 2013. Annual Report for Solid Waste Management in Egypt, 2013. Published by Ministry of State for Environmental Affairs. 
PROCESS ENGINEERING

\section{الملخص العربي \\ تقييم الطاقة الناتجة من المدفن الصحي بالحمام \\ د/هيثم حسين يوسف محمد*}

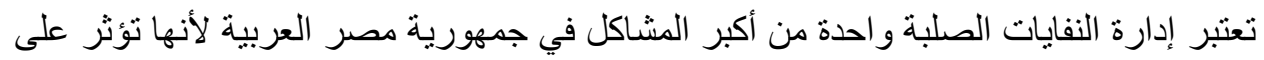

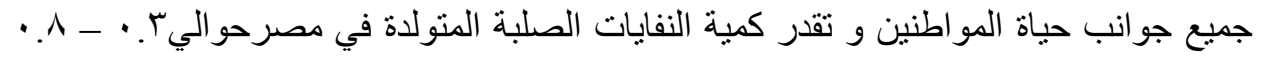

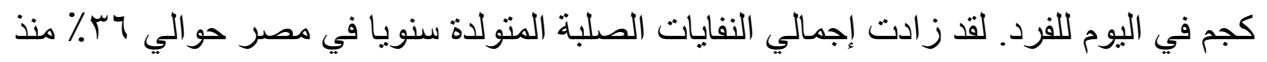

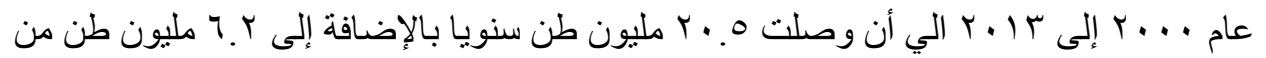

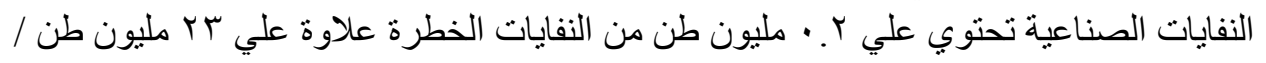

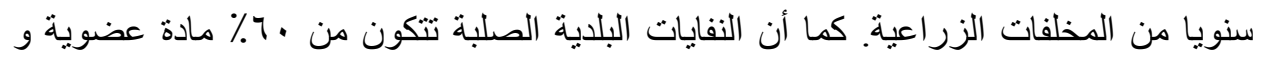

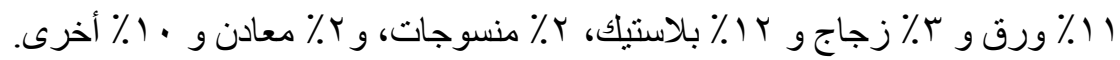

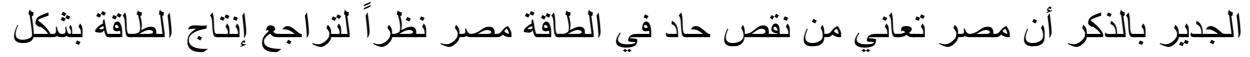

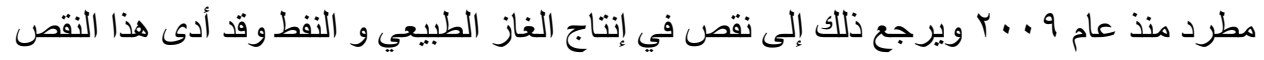

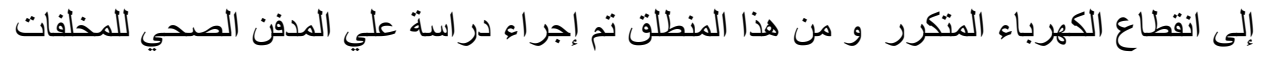

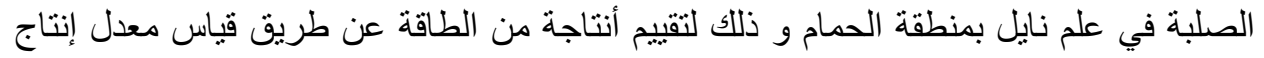

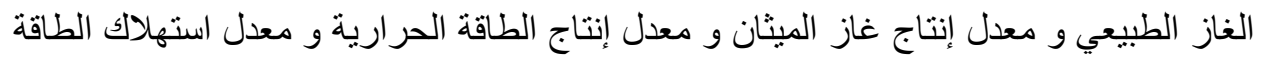
الكهربية ومعدل تدفق مياة الراشح و تقديم مقترح بالأستغلال الأمثل لهذة الغاز ات فئ في أنتاج

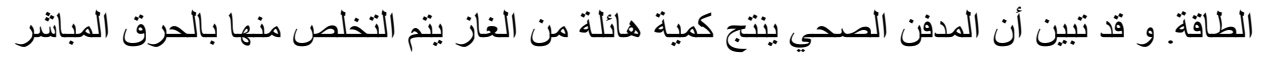

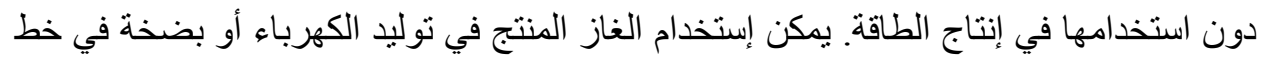

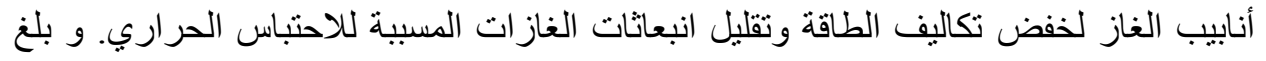
إجمالي إنتاج الغاز الطبيعي، و إجمالي إنتاج غاز الميثان، و إجمالي إنتاج الطاقة الحرارية و

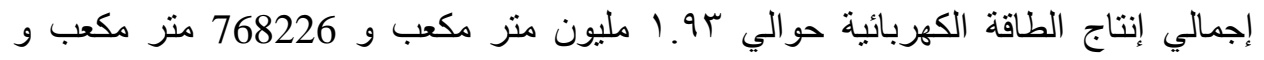

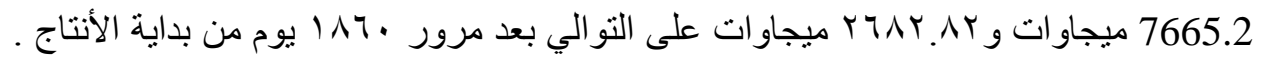
يستهلك المدفن الصحي حوالي بـ ميجاوات ساعة من الطاقة الكهربية في السنة و التي يتم

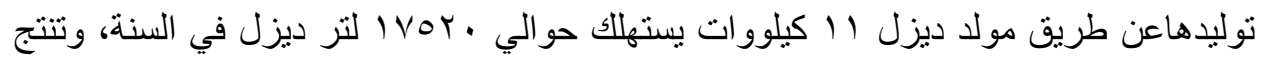

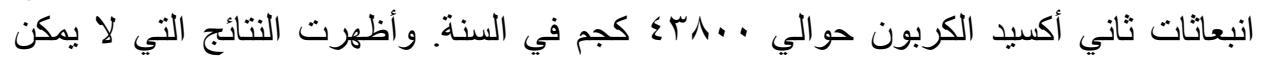

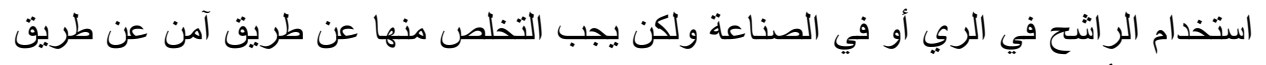
تبخير هاو أستخدامها مع توربينات البخارية لتوليد الكهرباء.

*مدرس الهندسة الزراعية ـ قسم الأراضي و الكيمياء الزراعية ـ كلية الزراعة ساباباشا ـ جامعة الأسكندرية. 